Government auspices, to the Veddas of Ceylon, where much valuable work of observation was done. Their material was embodied in "The Veddas" (1911), a standard work of which they were jointly the authors. Mrs. Seligman's work on this expedition was complementary to that of her husband, for in their association Seligman was giving practical effect for the first time to a plea which Dr. Haddon had long urged for the inclusion of women observers for obvious reasons in ethnographical expeditions among primitive peoples.

This association was continued when from 1909 onward Seligman became interested in Africa, and was engaged for some years under Government auspices in the study of the peoples of the Sudan, not only collecting the information which was embodied in "The Pagan Tribes of the Nilotic Sudan" (1932), but also laying the foundations of what is now the most efficient native survey service under British administration. Of the scientific importance of Seligman's discoveries among the Nilotic tribes in relation to the history of the kingship all readers of later editions of Frazer's "Golden Bough", as well as of his own Frazer Lecture, "Egypt and Negro Africa, a study in the Divine Kingship" (1934), are well aware. Another outcome of Seligman's African studies was an excellent little volume "The Races of Africa" in the "Home University Library".

Seligman was possessed of a highly developed artistic sense, which his scientific interests had fostered rather than blunted. It led him to the study of Chinese art and antiquities. He formed a small but choice collection, for which he built a museum at his home at Toot Baldon, and made his last journey of any considerable extent when in his later years he visited China to obtain a first-hand view of Chinese culture.

In 1910 Seligman was appointed lecturer in ethnology in the University of London and in 1918 he became professor in that subject, being attached to the London School of Economics, where he was associated with Prof. B. Malinowski. He retired in 1933, being granted the title of professor emeritus. The value of his work was widely recognized. In 1915, he was president of Section $H$ (Anthropology) of the British Association; in 1918 he was admitted to fellowship of the Royal Society; and he was president of the Royal Anthropological Institute during 1923-25. He was awarded both the Rivers Memorial Medal for work in the field (1925) and the Huxley Memorial Medal (1932) of the Royal Anthropological Institute, as well as the Annandale Memorial Medal of the Royal Asiatic Society of Bengal (1931).

The late C. G. Seligman and I were very old friends. We were born in the same year and met first at about the age of sixteen at the house of the late F. M. Halford, the greatest authority of his day on dry-fly fishing. We were both beginning to be interested in biology, and Halford was an enthusiast in microscopy, possessing a powerful binocular instrument with the then new oil-immersion lenses. We used to visit him on most Sunday afternoons; another of his young visitors being the late Edwin
Montagu, afterwards Secretary of State for India and a successful promoter of sanctuaries for rare birds.

Seligman proceeded from school to St. Thomas's Hospital, I to Cambridge. But we spent two summer holidays during these undergraduate years together, one on a walking tour in the New Forest, the other on a visit to Norway. Even in these early days his outstanding characteristics were his absorbing love for biological research, his power of concentration and his independence. His possession of independence was scarcely surprising, as he had lost both parents at an early age and was brought up in the homes of strangers.

Thus it was that in 1897, when the late A. C. Haddon was considering the personnel of his memorable expedition from Cambridge to the islands of the Torres Straits, New Guinea and Borneo, I (his old pupil) brought the two together, and Seligman accepted his nffer to join it. Under the guidance of Haddon and Kıvers, Seligman learnt his anthropology. At first he made a speciality of investigating native diseases and native treatment, collecting medicinal and other plants and information about the customs and rites of women during parturition and at puberty. But later his work during the expedition covered almost the whole field of anthropology.

While Rivers, McDougall and I were carrying out mainly psychological investigations in Murray Island, Seligman was for most of the time in New Guinea. While there, so keen became his interest in ethnology that he seriously considered the offer which he received of medical practice at Port Moresby.

The expedition decided Seligman's career in ethnology as it did mine in psychology. I have already mentioned his whole-hearted devotion to science, his perseverance and his thoroughness. His bravery in the face of continuous ill-health during later life is also noteworthy. To these qualities he added the wider social ones of blunt honesty and of unfailing loyalty to his friends.

C. S. MYERS

IN a message received from Sir James Frazer, he asks us to say he esteemed very highly Dr. Seligman's contribution to the science of man; he regrets that the state of his eyesight prevents him from making a fuller acknowledgment of the debt which he owed.

\section{Prof. L. O. M. von Rohr}

THE announcement of the death of Prof. Louis Otto Moritz von Rohr will be greatly regretted by his many scientific friends in Great Britain.

Prof. von Rohr was born at Lazyn, Kreis Hohensalza, Germany, on April 4, 1868, and had therefore reached the age of seventy-two.

At the University of Halle he was a student under the late Prof. G. Contor and obtained there the degree of Ph.D. in 1892. A few years thereafter at the age of twenty-seven he commenced his life-long association with the firm of Carl Zeiss as technical collaborator under the arrangement introduced by the late Prof. 
Abbe whereby young men of ability, while holding academic appointments, were engaged by Messrs. Zeiss, to the advantage of the collaborator and of the firm. They were afforded the opportunity, so often lacking elsewhere, of communicating direct to the firm the results of special research and of participating in the work of development, and in so doing of acquiring technical experience of the most advanced nature. Dr. Moritz von Rohr undoubtedly appreciated the importance of such a connexion and made the fullest use of his opportunities.

In 1913 von $R o h r$ received the additional appointment of assistant professor in the Department of Medical Optics at the University of Jena. His interests were soon diverted to the field of optics and particularly ophthalmics; but although he might have made a name for himself in the more creative field of research, he became at an early stage of his career greatly interested in the history of the science to which he had become devoted. Even in his earliest contributions the historical aspects of the subject tend to predominate over the more technical details.

Von Rohr soon became by far the most important writer in every branch of historical optics. Although his knowledge of previous writings was profound, much of his material was the result of personal research. To ensure the accuracy of the information, he travelled widely and was unsparing of his strength. Few writers on any one subject can ever have been the author of so many contributions. The list is of extraordinary length. Dr. von Rohr will be remembered not so much because of any outstanding original creative work, but rather as a historian who discovered and recorded much valuable material that otherwise would have been lost to the scientific world.

James Weir French.

\section{Prof. Hans Zinsser}

THe recent death in New York of Prof. Hans Zinsser, when he had nearly completed his sixty-second year, has removed an outstanding personality from the ranks of American bacteriologists. His work in the field of immunology and his researches during the past ten years into the prevention of typhus fever by means of a vaccine prepared from the causal organism had secured for him a world-wide reputation. Moreover, numerous interests, which extended far beyond the sphere of his scientific work, engaged his leisure hours, and thus he gave the impression of having lived intensely, even during the prolonged illness of which he clearly foresaw the inexorable end.

Zinsser was professor of bacteriology at Stanford University, California, from 1911 until 1913; at Columbia University, New York, from 1913 until 1923 ; and afterwards at Harvard Medical School, Boston. He was a member of the American Red Cross Sanitary Commission to Serbia in 1915; and in 1917 he served in the Medical Corps of the U.S. Army in France, where he acted as assistant director of the laboratories. In the summer of 1923 he visited Russia as sanitary commissioner for the Health Section of the League of Nations.
Problems investigated by Zinsser and his coworkers include : the mechanism of bacterial allergy ; the immunological significance of certain non-protein substances extracted from the tubercle bacillus and other bacterial species, a series of observations which were later illuminated by Avery and Heidelberger as a result of their pioneer work on the type-specific polysaccharides of the pneumococci; the essential identity of the various manifestations of the antibody reaction; a comparison of the precipitation and agglutination reactions as influenced by the surface, in the aggregate, of the antigenic particles exposed to the action of the antibody component; and-in a different category-studies on the causative virus of Brill's disease, of herpes and of typhus fever.

Zinsser was the author of a lucid, exceptionally well-written and deservedly popular text-book of immunology under the title "Resistance to Infectious Diseases" ; he prepared the latest edition with the aid of his colleagues Enders and Fothergill. His book "Rats, Lice and History", a popular account of the history and mode of transmission of typhus fever, won the good opinion of readers on both sides of the Atlantic not only by its solid background of knowledge but also by the numerous divagations from the main theme into the by-ways of literature and philosophy with which the reader is beguiled. $\mathrm{He}$ has also written an objective account of his life and experiences, which was recently published in the United States and has been acclaimed to be of unusual merit. We understand that the book will appear shortly in Great Britain, and we cannot doubt but that the self-portrait it contains will reveal the character of one whose interests ranged widely throughout the domains of thought and action and who, when his health finally broke down, met his fate with calm and even light-hearted courage. Perhaps, after all, it was for the best that a man of his intellectual energy should have been spared the "cruel disintegration of slow years", the tragedy of old age to which he thus alludes in the last sonnet he wrote.

G. F. Petrie.

WE regret to announce the following deaths :

Dr. William Bowie, president during 1933-36 of the International Union of Geodesy and Geophysics, on August 28, aged sixty-eight.

Prof. R. S. Dugan, professor of astronomy in Princeton University, on August 31, aged sixty-two.

Sir Henry Head, F.R.S., the eminent neurologist, former editor of Brain, on October 8, aged seventynine.

Prof. E. H. Lindley, professor of psychology in the University of Kansas during 1898-1917, on August 21, aged seventy-one.

Prof. H. H. Nicholson, professor of chemistry in the University of Nebraska during 1882-1905, on August 17, aged ninety-five.

Prof. Vito Volterra, For. Mem. R. S., formerly president of the International Committee of Weights and Measures, aged eighty. 